\title{
Overvekt og fedme hos norske barn
}

\author{
Overvekt og fedme hos barn øker. Foreldre er dårlige til å bedømme \\ barnas vekt, derfor er regelmessig måling og veiing i primærhelse- \\ tjenesten viktig.
}

Forekomsten av overvekt og fedme hos barn og unge har økt gradvis de siste 20-30 år. Kartlegging av dette er nødvendig for å kunne sette inn målrettede tiltak for å bedre barnas helse. Pétur B. Júlíusson er en av forskerne bak Vekststudien i Bergen (www.vekststudien.no), der man ser på utvikling av overvekt og fedme hos barn. - Vi ser en vektøkning blant barn de siste 30-40 år; særlig er de tyngste barna blitt tyngre. Det ser ut som om økt hudfoldtykkelse - altså økt mengde fettvev ligger bak. I aldersgruppen 2-19 år fant vi overvekt hos $13,8 \%$ og fedme hos $2,3 \%$. Forekomsten av overvekt og fedme var høyest i barneskolealder. Vi så ingen kjønnsforskjeller i gruppen totalt, men blant førskolebarna var det flere overvektige jenter og blant tenåringene flere overvektige gutter. Studien viser at det er økt risiko for overvekt og fedme hos barn av foreldre med lav utdanning, mens foreldrenes arbeidsforhold eller etniske opphav har lite å si, sier Júlíusson.

Foreldre har en tendens til å feilvurdere barnas vekt: Over $70 \%$ av de overvektige barna ble vurdert som normalvektige av foreldrene, det samme gjaldt over $40 \%$ av de undervektige.

- Dette viser hvor viktig det er med regelmessige målinger av høyde og vekt hos barn, sier Júlíusson. Han forsvarte avhandlingen Overweight and obesity in Norwegian children for ph.d-graden ved Universitetet i Bergen 22.10. 2010.

\section{Anne Forus}

anneforu@online.no

Tidsskriftet

\section{Ordforklaringer}

Vekststudien i Bergen: I perioden 2003-06 ble ti antropometriske mål, bl.a. høyde, vekt og hudfoldtykkelse - et mål for underhudsfett - målt hos 8299 barn og unge i Bergen. Deltakerne var i alderen 0-21 år og ble rekruttert fra tilfeldig utvalgte helsestasjoner, barnehager og skoler. Barnas helse og livsstil ble kartlagt ved hjelp av et spørreskjema, utfylt av foreldrene. Data fra denne studien ble sammenliknet med data fra en tilsvarende studie utført i perioden $1971-74$

Overvekt: Ifølge kriterier fra International Obesity Task Force kroppsmasseindeks (BMI) > $25 \mathrm{~kg} / \mathrm{m}^{2}$ ekstrapolert ned i alder.

Fedme: Ifølge kriterier fra International Obesity Task Force BMI > 30 kg/m² ekstrapolert ned i alder.

\section{Hvordan hemme barnekreft?}

\author{
Nevroblastom er en av de vanligste krefttypene hos barn. \\ Nå kan forskere ha funnet en måte å hemme kreftcelledelingen på. \\ Dermed blir svulsten mindre aggressiv.
}

Hvert år får rundt ti norske barn nevroblastom. Symptomene kan være kul i halsen eller mageregionen. Den aggressive varianten av nevroblastom er vanskelig å behandle, og dødeligheten er høy. I noen tilfeller er dessuten kreftcellene resistente mot cellegift. De mest aggressive nevroblastomene har ofte unormalt mange kopier av kreftgenet $M Y C N$. Dette genet er en viktig årsak til at cellene deler seg ukontrollert og dermed forårsaker kreftsvulst, og det er disse cellene som ofte er resistente mot cellegift.

Jørn Remi Henriksen og medarbeidere ved Universitetet i Tromsø har forsket på hvordan man kan hemme kreftcelledelingen.

- Vi har funnet ut mer om hva dette $M Y C N$-genet gjør med kreftcellen og hva som skjer når man slår ut onkogenet på langvarig basis. Vi har laget en modell som kan inaktivere det, og i laboratorieforsøk viser det seg at aggressiviteten dempes radikalt, sier Henriksen.

Forsøkene er hittil gjort i dyrkede kreftceller isolert fra svulster fra barn med nevroblastom. Nå vil de prøve ut dette i dyreforsøk. Ved siden av å slå ut genet kan man tilsette ulike medikamenter. På sikt er håpet dermed å kunne utvikle medikamenter som sammen med hemming av $M Y C N$ genet kan tas i bruk i pasientbehandling.

Henriksen disputerte for ph.d.-graden ved Universitetet i Tromsø 3.12. 2010, med avhandlingen Targeted MYCN suppression and its effect on miRNA in neuroblastoma.

\section{Eline Feiring}

eline.feiring@legeforeningen.no

Tidsskriftet

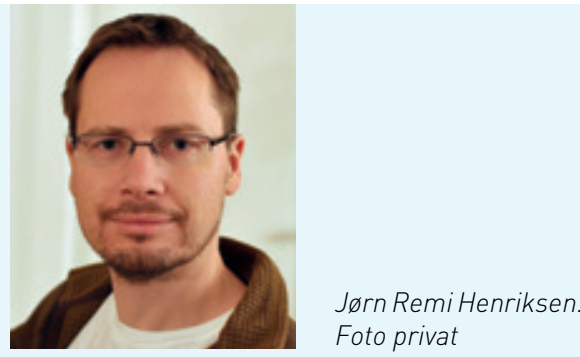

\section{Ordforklaringer}

Nevroblastom: Sjelden svulstform. Det er om lag 8-10 nye tilfeller i Norge per år. De aller fleste som rammes er spedbarn og småbarn. Forløpet er svært mangeartet. En del blir spontant friske uten behandling og trenger kun observasjon, andre dør på tross av intensiv multimodal behandling.

MYCN-genet: Gen som uttrykkes i fosteret under danningen av det sympatiske nervesystem. Dersom dette genet blir amplifisert i stedet for skrudd av, vil de rammede cellene få økt cellevekst, mindre grad av modning og vil som oftest danne aggressive tumorer. 